\title{
Timing of norepinephrine initiation in patients with septic shock: a systematic review and meta-analysis
}

\author{
Yuting Li, Hongxiang Li and Dong Zhang*
}

\begin{abstract}
Background: The effect of the timing of norepinephrine initiation on clinical outcomes in patients with septic shock is uncertain. A systematic review and meta-analysis was performed to evaluate the impact of early and late start of norepinephrine support on clinical outcomes in patients with septic shock.

Methods: We searched the PubMed, Cochrane, and Embase databases for randomized controlled trials (RCTs) and cohort studies from inception to the 1st of March 2020. We included studies involving adult patients (> 18 years) with septic shock. All authors reported our primary outcome of short-term mortality and clearly comparing early versus late norepinephrine initiation with clinically relevant secondary outcomes (ICU length of stay, time to achieved target mean arterial pressure $(\geq 65 \mathrm{mmHg}$ ), and volume of intravenous fluids within $6 \mathrm{~h}$ ). Results were expressed as odds ratio (OR) and mean difference (MD) with accompanying 95\% confidence interval (Cl).

Results: Five studies including 929 patients were included. The primary outcome of this meta-analysis showed that the short-term mortality of the early group was lower than that of the late group (odds ratio $[\mathrm{OR}]=0.45 ; 95 \% \mathrm{Cl}$, 0.34 to $0.61 ; P<0.00001 ; X^{2}=3.74 ; P^{2}=0 \%$ ). Secondary outcomes demonstrated that the time to achieved target MAP of the early group was shorter than that of the late group (mean difference $=-1.39 ; 95 \% \mathrm{Cl},-1.81$ to -0.96 ; $\left.P<0.00001 ; X^{2}=1.03 ; P^{2}=0 \%\right)$. The volume of intravenous fluids within $6 \mathrm{~h}$ of the early group was less than that of the late group (mean difference $=-0.50 ; 95 \% \mathrm{Cl},-0.68$ to $-0.32 ; P<0.00001 ; X^{2}=33.76 ; P^{2}=94 \%$ ). There was no statistically significant difference in the ICU length of stay between the two groups (mean difference $=-0.11 ; 95 \%$ $\mathrm{Cl},-1.27$ to $\left.1.05 ; P=0.86 ; X^{2}=0.85 ; P^{2}=0 \%\right)$.
\end{abstract}

Conclusions: Early initiation of norepinephrine in patients with septic shock was associated with decreased shortterm mortality, shorter time to achieved target MAP, and less volume of intravenous fluids within $6 \mathrm{~h}$. There was no significant difference in ICU length of stay between early and late groups. Further large-scale RCTs are still required to confirm these results.

Keywords: Timing, Norepinephrine initiation, Septic shock, Systematic review, Meta-analysis

\footnotetext{
* Correspondence: zhangdong21245@sina.com

Department of Intensive Care Unit, The First Hospital of Jilin University,

Changchun 130021, Jilin, China
}

(c) The Author(s). 2020 Open Access This article is licensed under a Creative Commons Attribution 4.0 International License, which permits use, sharing, adaptation, distribution and reproduction in any medium or format, as long as you give appropriate credit to the original author(s) and the source, provide a link to the Creative Commons licence, and indicate if changes were made. The images or other third party material in this article are included in the article's Creative Commons licence, unless indicated otherwise in a credit line to the material. If material is not included in the article's Creative Commons licence and your intended use is not permitted by statutory regulation or exceeds the permitted use, you will need to obtain permission directly from the copyright holder. To view a copy of this licence, visit http://creativecommons.org/licenses/by/4.0/ The Creative Commons Public Domain Dedication waiver (http://creativecommons.org/publicdomain/zero/1.0/) applies to the data made available in this article, unless otherwise stated in a credit line to the data. 


\section{Key messages}

- Early initiation of norepinephrine in patients with septic shock was associated with decreased shortterm mortality, shorter time to achieved target MAP, and less volume of intravenous fluids within $6 \mathrm{~h}$.

- There was no significant difference in ICU length of stay between early and late groups.

- More prompt and aggressive norepinephrine administration should be considered as part of initial resuscitation therapy for septic shock.

\section{Background}

Septic shock is one of the most challenging problems in critical care medicine. With an increasing annual incidence in the developed world, mortality remains between 25 and $50 \%$ of those afflicted [1-3]. Patients with septic shock can be identified with a clinical construct of sepsis with persisting hypotension requiring vasopressors to maintain mean arterial pressure (MAP) $\geq 65 \mathrm{mmHg}$ and having a serum lactate level $>2 \mathrm{mmol} / \mathrm{L}(18 \mathrm{mg} / \mathrm{dL})$ despite adequate volume resuscitation [4]. The 2018 Surviving Sepsis Campaign (SSC) Bundle recommends administering broad-spectrum antibiotics, rapidly administering $30 \mathrm{ml} / \mathrm{kg}$ crystalloid for hypotension or lactate $\geq 4 \mathrm{mmol} / \mathrm{L}$ and applying vasopressors if the patient is hypotensive during or after fluid resuscitation to maintain MAP $\geq 65 \mathrm{mmHg}$ within the first hour [5].

The pathophysiology of septic shock is complex and involves vasodilatation, relative and absolute hypovolemia, myocardial dysfunction, increased metabolic rate, and altered regional and microvascular blood flow [6-9]. Besides relative and absolute hypovolemia, decreased vascular tone is one of the major characteristics of septic shock causing hypotension [10]. Norepinephrine is both an alpha1- and beta1-agonist and is therefore able to increase vascular tone and contractility [11]. Recent guidelines recommend norepinephrine as the first-line vasopressor in septic shock [12].

So far, most studies have focused on the rational use of different types of vasopressors [13-15]. However, it is the timing of vasopressor therapy, rather than the specific agent, that appears to be crucial [16]. Studies comparing different agents have not clarified the optimal agents, and none have addressed the optimal timing [15, 17]. The present data show that the time from the onset of septic shock to initial norepinephrine administration is an important determinant of survival, but a recommendation on the timing to start norepinephrine support was not clearly stated [18].

Since the optimal timing of the initiation of norepinephrine remains unknown and whether the benefits or harm of norepinephrine introduction even preceding fluid resuscitation has not been still answered, we conducted a meta-analysis which extracted results from published randomized controlled trials (RCTs) and cohort studies to evaluate the impact of early and late start of norepinephrine support on clinical outcomes in patients with septic shock.

\section{Methods}

This systematic review and meta-analysis is reported according to the Preferred Reporting Items for Systematic Reviews and Meta-Analyses (PRISMA) guidelines [19]. Ethical approval was not necessary for this study because it was a review of the published literature.

\section{Search strategy}

We searched the PubMed, Cochrane, and Embase databases for studies from inception to the 1st of March 2020 using the following search terms: timing, time, early, earlier, delay, late, initiation, start, norepinephrine, vasopressor, and septic shock. The search was slightly adjusted according to the requirements of the different databases. The authors' personal files and reference lists of relevant review articles were also reviewed. The flow chart of the search strategies is summarized in Fig. 1.

\section{Types of outcome measures}

The primary outcome was short-term mortality; shortterm mortality included hospital mortality, 28-day mortality, and 30-day mortality. Secondary outcomes were intensive care unit (ICU) length of stay, time to achieved target MAP $(\geq 65 \mathrm{mmHg}$ ), and volume of intravenous fluids within $6 \mathrm{~h}$. Weighted means were calculated based on the number of patients in each study.

\section{Study selection}

The inclusion criteria were as follows: (1) RCTs as well as prospective and retrospective cohort studies; (2) adult patients ( $>18$ years) with septic shock, septic shock was classified according to the current Third International Consensus Definitions for Sepsis and Septic Shock (Sepsis 3.0), which considers the presence of suspected infection accompanying organ dysfunction, the use of vasopressors, MAP $<65 \mathrm{mmHg}$, and lactate levels $>2 \mathrm{mmol} / \mathrm{L}$ [4]; (3) all authors reported our primary outcome of short-term mortality; (4) and clearly comparing early versus late norepinephrine initiation with clinically relevant secondary outcomes. We excluded studies [20, 21] without clear comparisons of the outcomes. In addition, we excluded review articles and studies about pediatric or animal.

\section{Quality assessment}

Two reviewers (YL and HL) independently performed quality assessment. The quality of studies was assessed using the Cochrane Collaboration's tool for RCTs [22], 


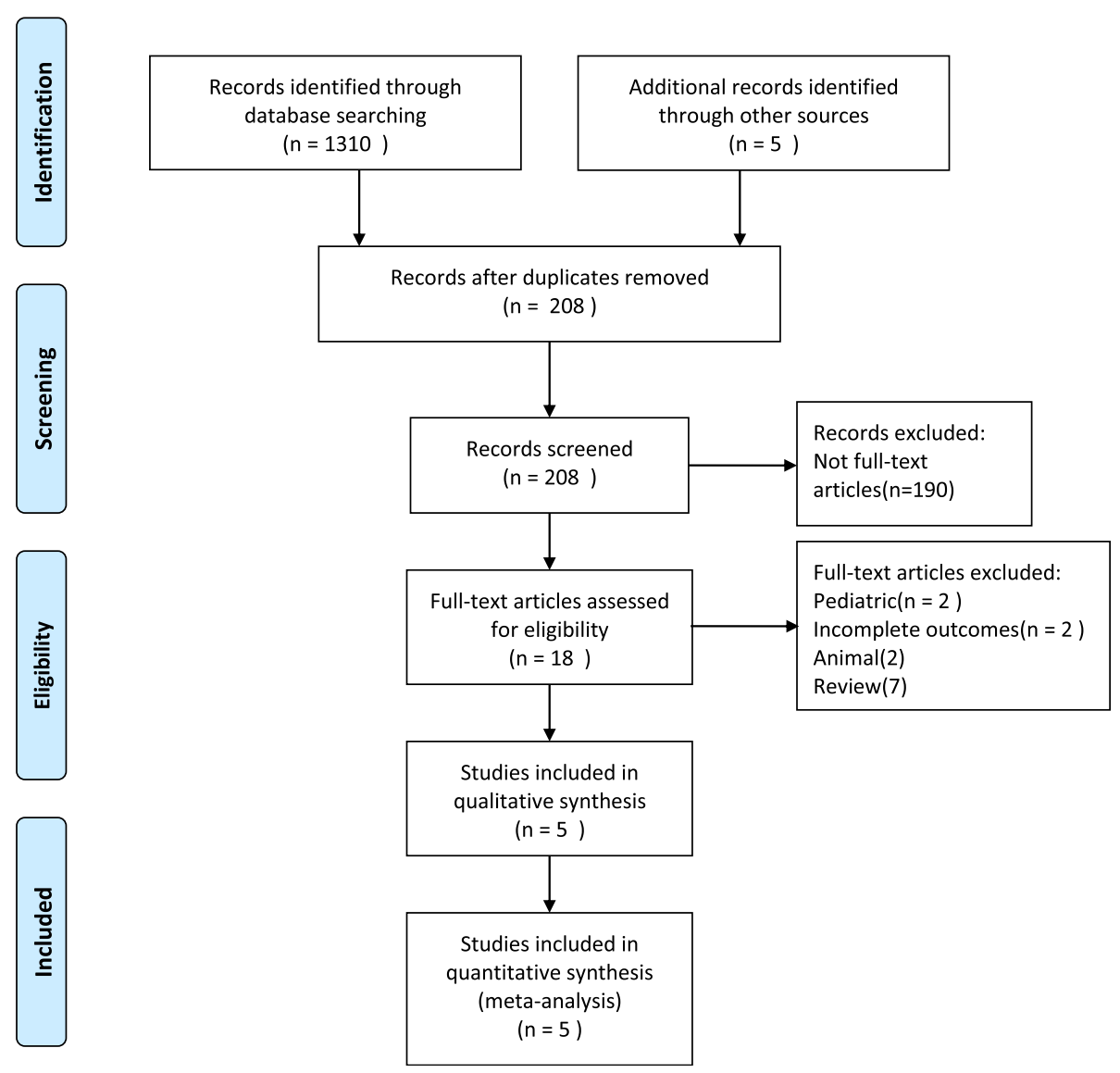

Fig. 1 Flow chart of literature selection

and the Newcastle-Ottawa Scale (NOS) was used for cohort studies [23]. The specific elements to minimize bias of RCTs were (1) randomization sequence (selection bias), (2) allocation concealment (selection bias), (3) blinding of study personnel and participants (performance bias), (4) blinding of outcome assessors (performance bias), (5) complete reporting of data without arbitrarily excluded patients and with low to minimal loss to follow-up (attrition bias), (6) selective reporting bias, and (7) other sources of bias. Satisfactory performance, unclear performance, and unsatisfactory performance of each domain from the tool are denoted by green, yellow, and red colors respectively. The risk of bias summary for included RCTs is presented in Supplement 1; the risk of bias graph for included RCTs is presented in Supplement 2.

NOS allocates a maximum of 9 points according to the quality of the selection, comparability, and outcomes of the cohort study populations. Study quality was defined as poor (0-3), fair (4-6), or good (7-9). The quality of the included cohort studies is presented in Table 1.

Table 1 Quality of the included cohort studies (The Newcastle-Ottawa Scale)

\begin{tabular}{|c|c|c|c|c|c|c|c|c|c|}
\hline \multirow[t]{2}{*}{ Study } & \multicolumn{4}{|l|}{ Selection } & \multirow[b]{2}{*}{$\begin{array}{l}\text { Comparability } \\
\text { Comparability } \\
\text { of cohorts on } \\
\text { the basis of } \\
\text { the design } \\
\text { or analysis }\end{array}$} & \multicolumn{3}{|l|}{ Outcome } & \multirow[b]{2}{*}{$\begin{array}{l}\text { Total } \\
\text { score }\end{array}$} \\
\hline & $\begin{array}{l}\text { Representativeness } \\
\text { of the exposed } \\
\text { cohort }\end{array}$ & $\begin{array}{l}\text { Selection of } \\
\text { the non- } \\
\text { exposed } \\
\text { cohort }\end{array}$ & $\begin{array}{l}\text { Ascertainment } \\
\text { of exposure }\end{array}$ & $\begin{array}{l}\text { Demonstration } \\
\text { that outcome } \\
\text { of interest was } \\
\text { not present at } \\
\text { the start of the } \\
\text { study }\end{array}$ & & $\begin{array}{l}\text { Assessment } \\
\text { of outcome }\end{array}$ & $\begin{array}{l}\text { Was follow- } \\
\text { up long } \\
\text { enough for } \\
\text { outcomes } \\
\text { to occur }\end{array}$ & $\begin{array}{l}\text { Adequacy } \\
\text { of follow- } \\
\text { up of } \\
\text { cohorts }\end{array}$ & \\
\hline Bai et al. 2014 [24] & 访 & 访 & 访 & 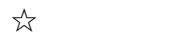 & 论沶 & $\hbar$ & 访 & 访 & 9 \\
\hline $\begin{array}{l}\text { Colon Hidalgo } \\
\text { et al. } 2020[25]\end{array}$ & $\hat{s}$ & $\hat{\imath}$ & $\sum$ & 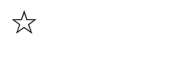 & 我坊 & 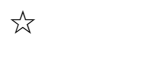 & 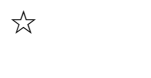 & 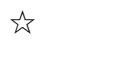 & 9 \\
\hline $\begin{array}{l}\text { Ospina-Tascón } \\
\text { et al. } 2020 \text { [26] }\end{array}$ & $\hat{s}$ & $\hat{\imath}$ & $\hat{\imath}$ & 幽 & 论坛 & 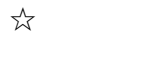 & 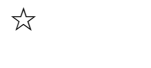 & 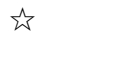 & 9 \\
\hline
\end{tabular}




\section{Statistical analysis}

Statistical analyses were performed using Review Manager version 5.3 (RevMan, The Cochrane Collaboration, Oxford, UK). Odds ratio (OR) with 95\% confidence intervals $(\mathrm{CI})$ was calculated for dichotomous variables. As to the continuous variables, mean difference (MD) and 95\% CI were estimated as the effect result. A randomeffects model was used to pool studies with significant heterogeneity, as determined by the chi-squared test $(P<0.10)$ and inconsistency index $\left(I^{2} \geq 50 \%\right)$ [27]. Some of the selected continuous variables were represented by the median (interquartile range). We calculated their mean and standard deviation according to the sample size with a calculator [28] and then performed a metaanalysis. A $P$ value $<0.05$ was set as the threshold of statistical significance. To reduce bias, we performed a subgroup analysis of RCTs and cohort studies.

\section{Result}

\section{Study characteristics}

The search strategy identified 1315 studies, and the data were from 2 RCTs and 3 cohort studies comprising 929 patients (Table 2) [24-26, 29, 30]. The characteristics of the included studies are shown in Table 2. A total of 5 eligible studies were published between 2014 and 2020 . Among these studies, one study was conducted in China, one study was conducted in Thailand, one study was conducted in Egypt, one study was conducted in the USA, and one study was conducted in Colombia. All of these studies were single-center studies. The definitions of early and late norepinephrine group in studies included in the meta-analysis are outlined in Table 3.

\section{Primary outcome}

A total of five studies including 929 patients were included, and the short-term mortality was about $29.3 \%$ $(101 / 467$ in the early group and 171/462 in the late group). The short-term mortality of the early group was lower than that of the late group (odds ratio $[\mathrm{OR}]=0.45$; 95\% CI, 0.34 to $0.61 ; P<0.00001 ; X^{2}=3.74 ; I^{2}=0 \%$ ) (Fig. 2). A funnel plot was used to assess the publication bias (Fig. 3).

\section{Secondary outcomes ICU length of stay}

Three of included studies were analyzed to assess the ICU length of stay (day). There was no statistically significant difference in the ICU length of stay between the two groups (mean difference $=-0.11 ; 95 \% \mathrm{CI},-1.27$ to $1.05 ; P=0.86 ; \chi^{2}=0.85 ; I^{2}=0 \%$ ) (Fig. 4).

\section{Time to achieved target MAP}

Three of the included studies were analyzed to assess the time to achieved target MAP (hour). The time to achieved target MAP of the early group was shorter than that of the late group (mean difference $=-1.39 ; 95 \% \mathrm{CI}$, -1.81 to $-0.96 ; P<0.00001 ; \chi^{2}=1.03 ; I^{2}=0 \%$ ) (Fig. 5).

\section{Volume of intravenous fluids within $6 \mathrm{~h}$}

Three of included studies were analyzed to assess the volume of intravenous fluids within $6 \mathrm{~h}(\mathrm{~L})$. The volume of intravenous fluids within $6 \mathrm{~h}$ of the early group was less than that of the late group (mean difference $=-$ $0.50 ; 95 \% \mathrm{CI},-0.68$ to $-0.32 ; P<0.00001 ; \chi^{2}=33.76$; $\left.I^{2}=94 \%\right)($ Fig. 6).

\section{Discussion}

This systematic review and meta-analysis of five studies including 929 patients compared early and late norepinephrine initiation in patients with septic shock. We found that the overall short-term mortality was about $29.3 \%$, and the short-term mortality of the early group was lower than that of the late group. Secondary outcomes showed that the time to achieved target MAP of the early group was shorter than that of the late group. The survival benefit of early and effective resuscitation is confirmed in septic shock patients [31]. This meta-analysis demonstrated that the significant mortality benefit with early initiation of a norepinephrine is likely secondary to earlier achievement and maintenance of adequate perfusion pressures, preventing the onset and/or progression of organ dysfunction [32]. This is also in line with another study suggesting that shorter hypotension times are associated with better outcomes in septic shock [33]. The patients with septic shock receiving vasopressors early or late depend on the patient's

Table 2 The basic characteristics of studies included in the meta-analysis

\begin{tabular}{llllllll}
\hline Author & Year & Country & Study period & Study design & \multicolumn{2}{c}{ No. of patients } \\
\cline { 5 - 8 } & & & & & Total & Early group & Late group \\
\hline Bai et al. [24] & 2014 & China & Jan. 2011-Dec. 2012 & Single center, retrospective cohort study & 213 & 86 & 127 \\
Permpikul et al. [29] & 2019 & Thailand & Oct. 2013-Mar. 2017 & Single center, RCT & 310 & 155 & 155 \\
Elbouhy et al. [30] & 2019 & Egypt & Jan. 2017-Dec. 2018 & Single center, RCT & 101 & 57 & 44 \\
Colon Hidalgo et al. [25] & 2020 & USA & Jan. 2017-Jul. 2017 & Single center, retrospective cohort study & 119 & 76 & 43 \\
Ospina-Tascón et al. [26] & 2020 & Colombia & Jan. 2015-Feb. 2017 & Single center, prospective cohort study & 186 & 93 & 93 \\
\hline
\end{tabular}


Table 3 Definitions of early and late norepinephrine group in studies included in the meta-analysis

\begin{tabular}{|c|c|c|}
\hline Study & Early group & Late group \\
\hline Bai et al. 2014 [24] & $\begin{array}{l}\text { Time from the onset of septic shock to initial } \\
\text { norepinephrine administration }<2 \mathrm{~h}\end{array}$ & $\begin{array}{l}\text { Time from the onset of septic shock to initial } \\
\text { norepinephrine administration } \geq 2 \mathrm{~h}\end{array}$ \\
\hline Permpikul et al. 2019 [29] & $\begin{array}{l}\text { Median time from emergency room arrival to } \\
\text { norepinephrine administration was } 93 \mathrm{~min}\end{array}$ & $\begin{array}{l}\text { Median time from emergency room arrival to } \\
\text { norepinephrine administration was } 192 \mathrm{~min}\end{array}$ \\
\hline Elbouhy et al. 2019 [30] & $\begin{array}{l}\text { Patients received initial resuscitation as simultaneous } \\
\text { administration of crystalloid fluids (the target was } \\
30 \mathrm{~mL} / \mathrm{kg} \text { ) together with norepinephrine infusion in } \\
\text { a starting dose of } 5 \mu \mathrm{g} / \mathrm{min} \text { administered in an } \\
\text { external jugular peripheral cannula }\end{array}$ & $\begin{array}{l}\text { Patients' resuscitation included crystalloid fluids } \\
\text { (the target was } 30 \mathrm{~mL} / \mathrm{kg} \text { ) and immediate ICU } \\
\text { transfer where the norepinephrine infusion was } \\
\text { administered only to patients with mean arterial } \\
\text { pressure }<65 \mathrm{mmHg} \text { after fluids resuscitation via } \\
\text { a central venous catheter }\end{array}$ \\
\hline Colon Hidalgo et al. 2020 [25] & The time when vasopressors were initiated $\leq 6 \mathrm{~h}$ & The time when vasopressors were initiated $>6 \mathrm{~h}$ \\
\hline Ospina-Tascón et al. 2020 [26] & $\begin{array}{l}\text { Vasopressor support initiated within the next hour or } \\
\text { even before the first fluid load with resuscitative } \\
\text { intention (FRLoad) }\end{array}$ & $\begin{array}{l}\text { Patients in whom vasopressor support was } \\
\text { started }>1 \mathrm{~h} \text { after the FRLoad }\end{array}$ \\
\hline
\end{tabular}

response to initial fluid resuscitation and the judgment of the physicians. If clinicians delay starting vasopressors because of a lack of critical care bed availability, then they probably should not delay. Managing a patient on a general ward, without vasopressors, hoping that in time blood pressure will improve and thus not require critical care, may lead to worse outcomes for patients [34]. Since the timing to start norepinephrine is crucial, one of the recommendations was to administer norepinephrine in the initial phase of septic shock even when hypovolemia is not completely corrected by fluid administration [35]. In addition, a low value of diastolic arterial pressure (e.g., < $40 \mathrm{mmHg}$ ) is strongly suggestive of a markedly depressed arterial tone and should prompt initiation of norepinephrine urgently [36].
Secondary outcomes demonstrated that the volume of intravenous fluids within $6 \mathrm{~h}$ of the early group was less than that of the late group. Fluid overload is a common complication during septic shock resuscitation. Two recent studies also showed that early use of norepinephrine is associated with less fluid administration and improved outcomes [37, 38]. Positive cumulative fluid balance is an independent factor of mortality in septic shock patients: the higher the positive fluid balance, the poorer the outcome [39-41]. A recent large cohort study of 23,513 patients with severe sepsis and septic shock showed that administration of more than $5 \mathrm{~L}$ of fluid during the first day is associated with a significantly increased risk of death [42]. The mechanisms by which excessive fluid administration may worsen outcome

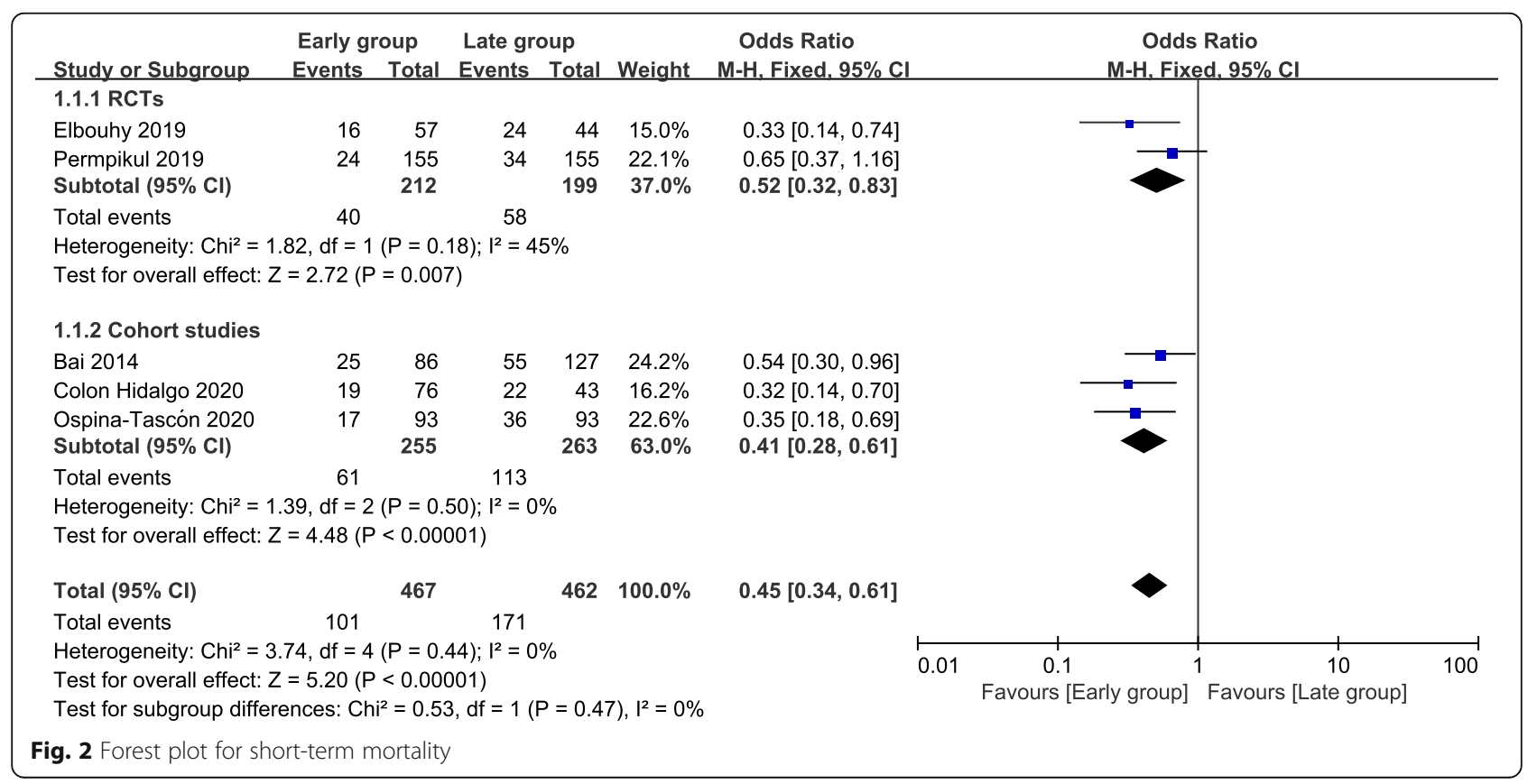




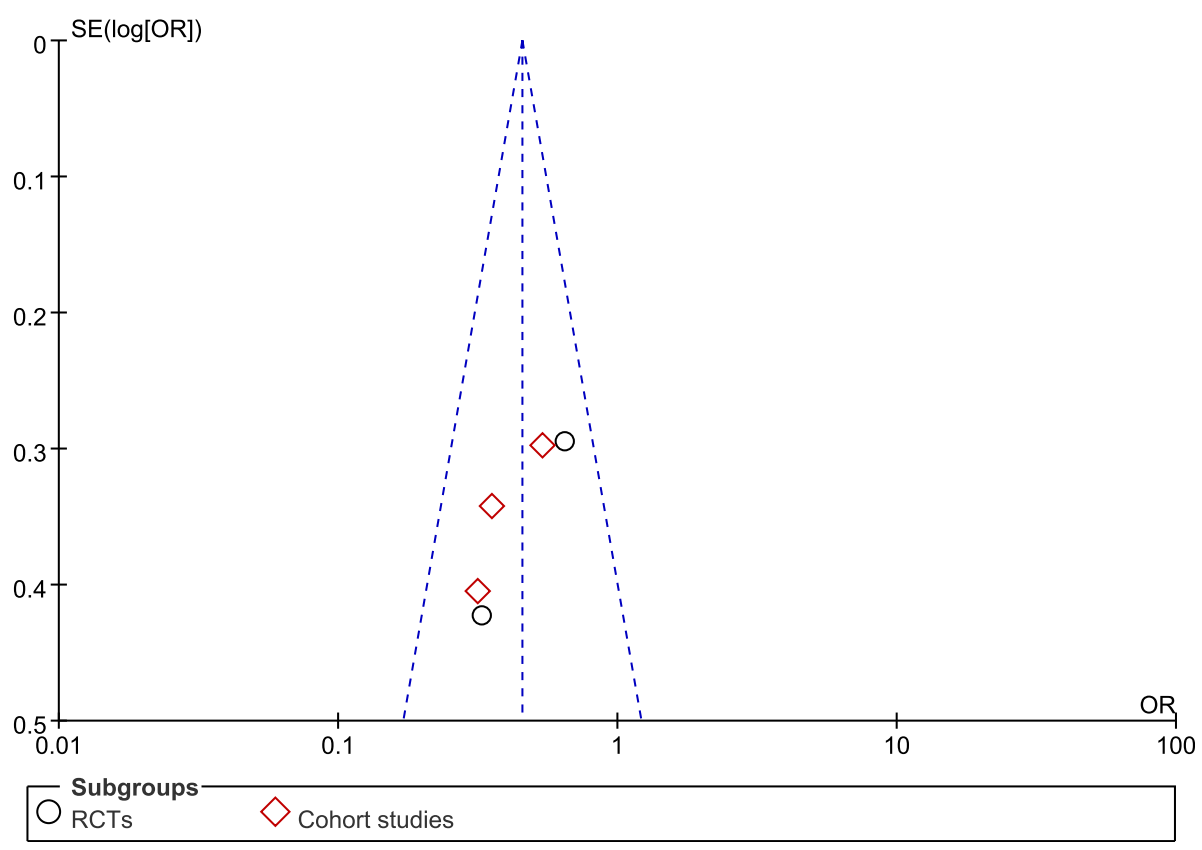

Fig. 3 Funnel plot for short-term mortality

include peripheral tissue edema with risks of multiple organ dysfunction, pulmonary edema with risks of profound hypoxemia, degradation of endothelial glycocalyx [43] with risks of increased vascular permeability, marked increase in venous pressures with risks of decrease in organ perfusion pressure [44], and hemodilution [45]. Early use of norepinephrine decreases the use of fluid replacement, possibly by constricting the dilated vascular bed, and shortens resuscitation duration [46]. In addition, our metaanalysis showed that there was no statistically significant difference in the ICU length of stay between the two groups. Delay in vasopressor initiation was not predictive of ICU length [47].

Early norepinephrine use in septic shock can increase cardiac output through an increase in cardiac preload and/or contractility and improve microcirculation and tissue oxygenation [36]. However, the use of vasopressors is not without consequences. Risk of well-known adverse reactions, such as arrhythmias, may have been increased for patients with prolonged exposure to vasopressors, potentially adding to the increased mortality rate. Another main argument is that high doses of exogenous norepinephrine may have deleterious consequences such as myocardial cell injury, oxidative stress, and alteration of sepsisassociated immunomodulation [48]. Splanchnic hypoperfusion is also an important concern when norepinephrine is given early. No matter what, norepinephrine remains the primary vasopressor in septic shock, and the existing evidence suggests that it remains a safe and effective first-line medication for septic shock.

At present, there is no uniform definition of "early" or "late" norepinephrine initiation in patients with septic shock, and the five studies included in our meta-analysis have different definitions of the early and late groups. We listed a table (Table 3) to illustrate each author's definition of the early and late groups. The recent Hour-1 Bundle supported by the SSC recommends starting vasopressors within the first hour of resuscitation if initial fluid loading does not

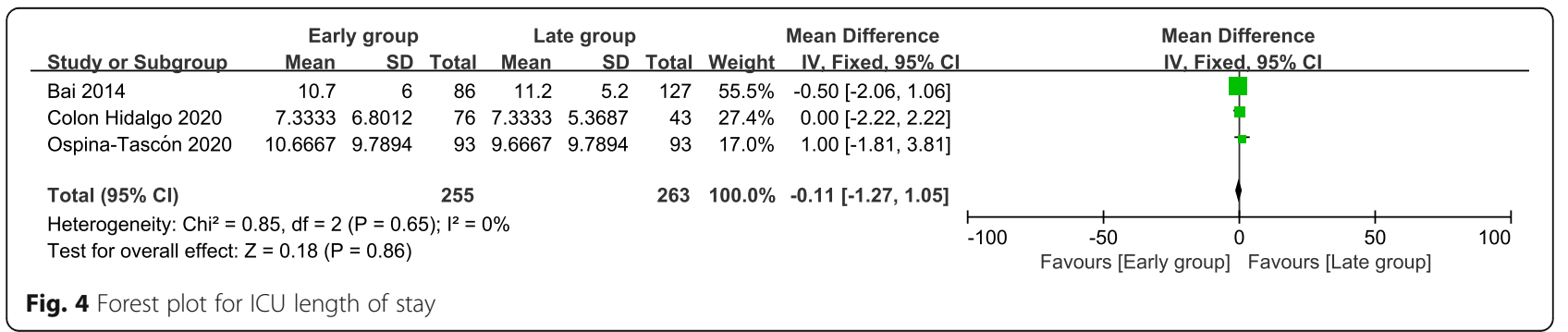




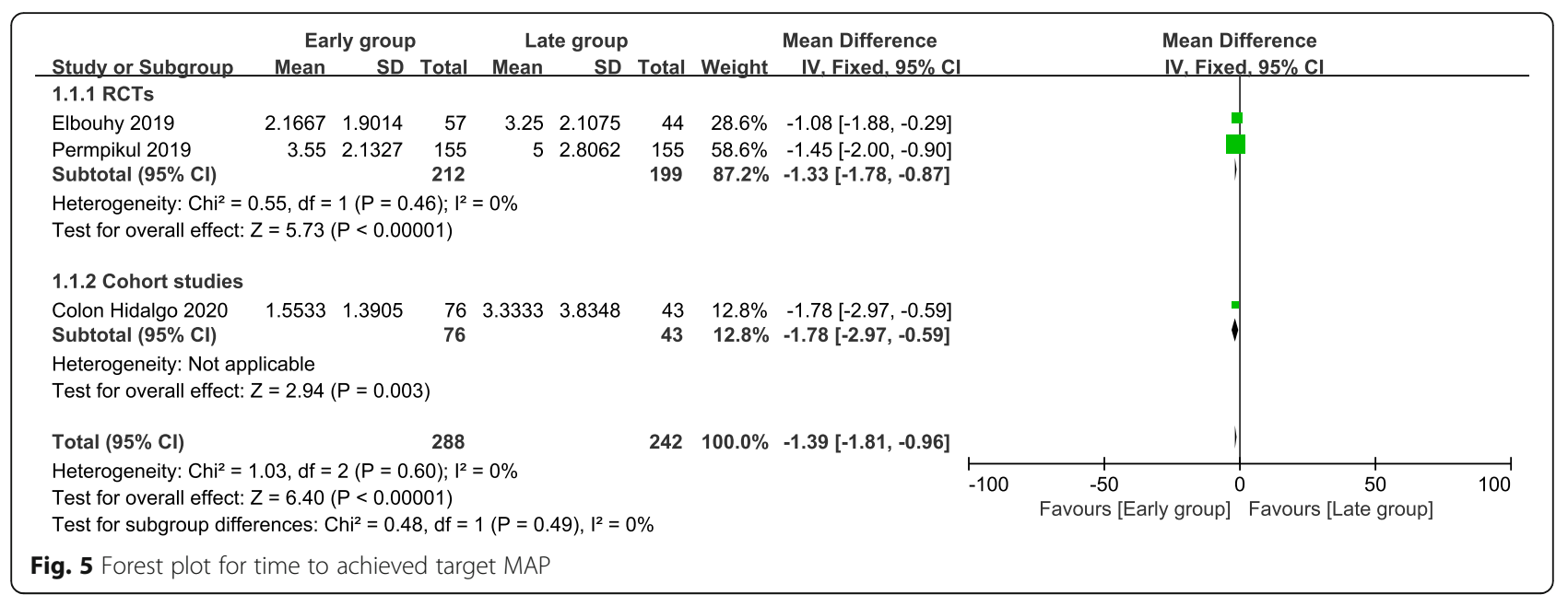

restore minimum MAP [5]. Indeed, norepinephrine infusion can be safely started before ICU admission, even in intermediate care without intensivist supervision. Delays in initiation of vasopressor therapy following the first documentation of hypotension in septic shock are modestly associated with increased specific organ failure and mortality risk. We now need a large multicenter phase 3 RCT of early norepinephrine initiation powered for mortality and organ dysfunction. In a word, early may be better.

This meta-analysis and the five included studies have several characteristics. First, the effect of the timing of norepinephrine initiation on short-term mortality is different in the five included studies. Therefore, the metaanalysis of different studies with different conclusions adds to the significance of this study. Second, although the primary outcomes of the five studies are inconsistent, the secondary outcomes, including the time to achieved target MAP and ICU length of stay, are consistent. This will reinforce the secondary outcomes of this meta-analysis.

Our meta-analysis has several limitations. First, the number of included studies is small. Further randomized clinical studies should be conducted in order to confirm the results. Second, many of the secondary outcomes such as ICU length of stay, time to achieved target MAP, or volume of intravenous fluids within $6 \mathrm{~h}$ were not included in all of the studies examined in this meta-analysis. Third, organ dysfunction is also a very important clinical outcome. However, few included studies had shown this data. Fourth, although we had performed a subgroup analysis of RCTs and cohort studies, there was still substantial heterogeneity among the included studies. Very heterogeneous populations were included in both randomized and observational studies. In addition, inclusion/exclusion criteria and comorbidities were widely different among included studies which supposed a limitation to interpret results. Therefore, our findings should be interpreted with caution.

\section{Conclusion}

Early initiation of norepinephrine in patients with septic shock was associated with decreased short-term mortality, shorter time to achieved target MAP, and less volume of intravenous fluids within $6 \mathrm{~h}$. There was no significant difference in ICU length of stay between early and late groups. These results suggest that more prompt and aggressive norepinephrine administration should be considered as part of initial resuscitation therapy for septic shock. Further large-scale RCTs are still required to confirm these results.

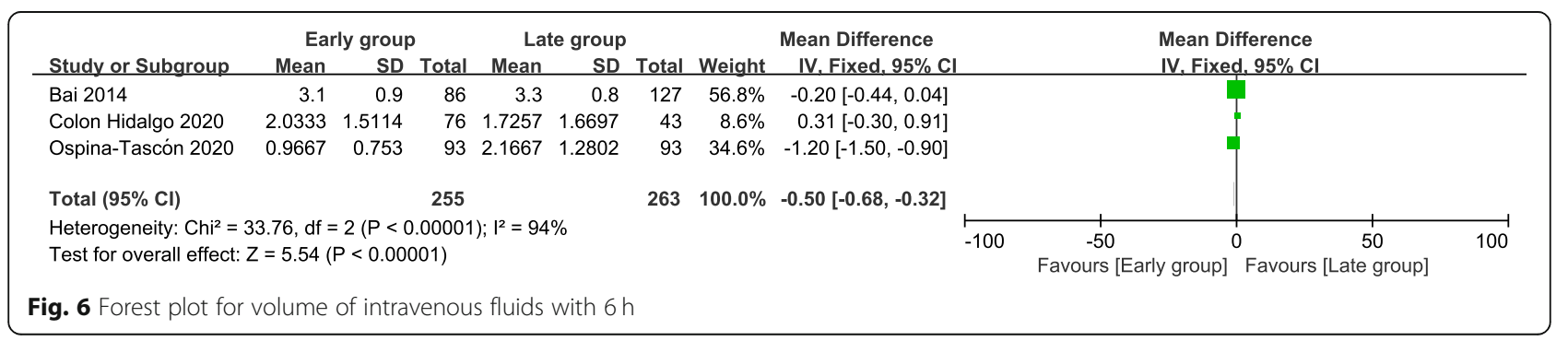




\section{Supplementary information}

Supplementary information accompanies this paper at https://doi.org/10. 1186/s13054-020-03204-x.

Additional file 1: Supplement 1. Risk of bias summary: review authors' judgements about each risk of bias item for each included RCTs.

Additional file 2: Supplement 2. Risk of bias graph: review authors' judgements about each risk of bias item presented as percentages across all included RCTs.

\section{Abbreviations}

MAP: Mean arterial pressure; SSC: Surviving Sepsis Campaign;

RCTs: Randomized controlled trials; ICU: Intensive care unit; PRISMA: Preferred Reporting Items for Systematic Reviews and Meta-Analyses; NOS: NewcastleOttawa Scale; OR: Odds ratio; MD: Mean difference; Cl: Confidence interval

\section{Acknowledgements}

Not applicable.

\section{Authors' contributions}

$\mathrm{YL}$ searched the scientific literature and drafted the manuscript. $\mathrm{HL}$ contributed to the conception, design, and data interpretation. HL also helped to collect the data and performed statistical analyses. DZ contributed to the conception, design, data interpretation, manuscript revision for critical intellectual content, and supervision of the study. All authors read and approved the manuscript.

\section{Funding}

This work was supported by the Project of Natural Science Foundation of Jilin Province (no. 20160101142JC)

\section{Availability of data and materials}

All data generated or analyzed during this study are included in this published article.

\section{Ethics approval and consent to participate}

Not applicable.

\section{Consent for publication}

Not applicable.

\section{Competing interests}

The authors declare that they have no competing interests.

Received: 15 March 2020 Accepted: 26 July 2020

Published online: 06 August 2020

\section{References}

1. Martin GS, Mannino DM, Eaton S, Moss M. The epidemiology of sepsis in the United States from 1979 through 2000. N Engl J Med. 2003;348(16): 1546-54.

2. Kumar A, Ellis P, Arabi Y, Roberts D, Light B, Parrillo JE, Dodek P, Wood G, Kumar A, Simon D, et al; Cooperative Antimicrobial Therapy of Septic Shock Database Research Group. Initiation of inappropriate antimicrobial therapy results in a fivefold reduction of survival in human septic shock. Chest 2009; 136(5):1237-1248.

3. Ranieri VM, Thompson BT, Barie PS, Dhainaut JF, Douglas IS, Finfer S, Gårdlund B, Marshall JC, Rhodes A, Artigas A, et al. Drotrecogin alfa (activated) in adults with septic shock. N Engl J Med. 2012;366(22):2055-64.

4. Singer M, Deutschman CS, Seymour CW, Shankar-Hari M, Annane D, Bauer M, Bellomo R, Bernard GR, Chiche JD, Coopersmith CM, et al. The third international consensus definitions for sepsis and septic shock (Sepsis-3). JAMA. 2016:315(8):801-10.

5. Levy MM, Evans LE, Rhodes A. The surviving sepsis campaign bundle: 2018 update. Intensive Care Med. 2018:44(6):925-8.

6. De Backer D, Creteur J, Preiser JC, Dubois MJ, Vincent JL. Microvascular blood flow is altered in patients with sepsis. Am J Respir Crit Care Med. 2002;166(1):98-104.
7. Sakr Y, Dubois MJ, De Backer D, Creteur J, Vincent JL. Persistent microcirculatory alterations are associated with organ failure and death in patients with septic shock. Crit Care Med. 2004;32(9):1825-31.

8. LeDoux D, Astiz ME, Carpati CM, Rackow EC. Effects of perfusion pressure on tissue perfusion in septic shock. Crit Care Med. 2000;28(8):2729-32.

9. Annane D, Bellissant E, Cavaillon JM. Septic shock. Lancet. 2005;365(9453): 63-78.

10. Hamzaoui O, Scheeren TWL, Teboul JL. Norepinephrine in septic shock: when and how much? Curr Opin Crit Care. 2017;23(4):342-7.

11. Annane D, Ouanes-Besbes L, de Backer D, DU B, Gordon AC, Hernández G, Olsen KM, Osborn TM, Peake S, Russell JA, et al. A global perspective on vasoactive agents in shock. Intensive Care Med. 2018;44(6):833-46.

12. Rhodes A, Evans LE, Alhazzani W, Levy MM, Antonelli M, Ferrer R, Kumar A Sevransky JE, Sprung CL, Nunnally ME, et al. Surviving Sepsis Campaign: international guidelines for management of sepsis and septic shock: 2016. Intensive Care Med. 2017:43(3):304-77.

13. Sandifer JP, Jones AE. Is the addition of vasopressin to norepinephrine beneficial for the treatment of septic shock. Ann Emerg Med. 2013;62(5): 534-5.

14. Daley MJ, Lat I, Mieure KD, Jennings HR, Hall JB, Kress JP. A comparison of initial monotherapy with norepinephrine versus vasopressin for resuscitation in septic shock. Ann Pharmacother. 2013;47(3):301-10.

15. Russell JA, Walley KR, Singer J, Gordon AC, Hébert PC, Cooper DJ, Holmes CL, Mehta S, Granton JT, Storms MM, et al; VASST Investigators. Vasopressin versus norepinephrine infusion in patients with septic shock. N Engl J Med 2008:358(9):877-887.

16. Parrillo JE. Septic shock-vasopressin, norepinephrine, and urgency. N Engl J Med. 2008:358(9):954-6.

17. Sakr Y, Reinhart K, Vincent JL, Sprung CL, Moreno R, Ranieri VM, De Backer $D$, Payen D. Does dopamine administration in shock influence outcome? Results of the Sepsis Occurrence in Acutely III Patients (SOAP) Study. Crit Care Med. 2006:34(3):589-97.

18. Rhodes A, Evans LE, Alhazzani W, Levy MM, Antonelli M, Ferrer R, Kumar A Sevransky JE, Sprung CL, Nunnally ME, et al. Surviving Sepsis Campaign: international guidelines for management of sepsis and septic shock: 2016. Crit Care Med. 2017:45(3):486-552.

19. Moher D, Liberati A, Tetzlaff J, Altman DG; PRISMA Group. Preferred reporting items for systematic reviews and meta-analyses: the PRISMA statement. Open Med 2009;3(3):e123-e130.

20. Hamzaoui O, Georger JF, Monnet X, Ksouri H, Maizel J, Richard C, Teboul JL. Early administration of norepinephrine increases cardiac preload and cardiac output in septic patients with life-threatening hypotension. Crit Care. 2010;14(4):R142.

21. Morimatsu H, Singh K, Uchino S, Bellomo R, Hart G. Early and exclusive use of norepinephrine in septic shock. Resuscitation. 2004:62(2):249-54.

22. Higgins JPT, Sally G. Cochrane Handbook for Systematic Reviews of Interventions, version 5.1.0. 2016. Available at: http://training.cochrane.org/ handbook. Accessed 23 Dec 2016.

23. Wells GA, Shea BJ, O'connell D, et al. The Newcastle-Ottawa Scale (NOS) for assessing the quality of non-randomized studies in meta-analysis. Appl Eng Agric. 2014;18:727-34

24. Bai X, Yu W, Ji W, Lin Z, Tan S, Duan K, Dong Y, Xu L, Li N. Early versus delayed administration of norepinephrine in patients with septic shock. Crit Care. 2014;18(5):532

25. Colon Hidalgo D, Patel J, Masic D, Park D, Rech MA. Delayed vasopressor initiation is associated with increased mortality in patients with septic shock. J Crit Care. 2020:55:145-8.

26. Ospina-Tascón GA, Hernandez G, Alvarez I, Calderón-Tapia LE, ManzanoNunez R, Sánchez-Ortiz Al, Quiñones E, Ruiz-Yucuma JE, Aldana JL, Teboul $J$, et al. Effects of very early start of norepinephrine in patients with septic shock: a propensity score-based analysis. Crit Care. 2020;24(1):52.

27. Biggerstaff BJ, Jackson D. The exact distribution of Cochran's heterogeneity statistic in one-way random effects meta-analysis. Stat Med. 2008;27(29): 6093-110

28. Wan X, Wang W, Liu J, Tong T. Estimating the sample mean and standard deviation from the sample size, median, range and/or interquartile range. BMC Med Res Methodol. 2014;14:135

29. Permpikul C, Tongyoo S, Viarasilpa T, Trainarongsakul T, Chakorn T, Udompanturak S. Early use of norepinephrine in septic shock resuscitation (CENSER). A randomized trial. Am J Respir Crit Care Med. 2019:199(9):1097105. 
30. Elbouhy MA, Soliman M, Gaber A, Taema KM, Abdel-Aziz A. Early use of norepinephrine improves survival in septic shock: earlier than early. Arch Med Res. 2019;50(6):325-32.

31. Coba V, Whitmill M, Mooney R, Horst HM, Brandt MM, Digiovine B, Mlynarek M, McLellan B, Boleski G, Yang J, et al. Resuscitation bundle compliance in severe sepsis and septic shock: improves survival, is better late than never. J Intensive Care Med. 2011;26(5):304-13.

32. Varpula M, Tallgren M, Saukkonen K, Voipio-Pulkki LM, Pettilä V. Hemodynamic variables related to outcome in septic shock. Intensive Care Med. 2005;31(8):1066-71.

33. Dünser MW, Takala J, Ulmer H, Mayr VD, Luckner G, Jochberger S, Daudel F, Lepper P, Hasibeder WR, Jakob SM. Arterial blood pressure during early sepsis and outcome. Intensive Care Med. 2009:35(7):1225-33.

34. Russell JA, Gordon AC, Walley KR. Early may be better: early low-dose norepinephrine in septic shock. Am J Respir Crit Care Med. 2019;199(9): 1049-51.

35. Scheeren TWL, Bakker J, De Backer D, Annane D, Asfar P, Boerma EC, Cecconi M, Dubin A, Dünser MW, Duranteau J, et al. Current use of vasopressors in septic shock. Ann Intensive Care. 2019;9(1):20.

36. Hamzaoui O, Shi R. Early norepinephrine use in septic shock. J Thorac Dis. 2020;12(Suppl 1):S72-7.

37. Ranjit S, Natraj R, Kandath SK, Kissoon N, Ramakrishnan B, Marik PE. Early norepinephrine decreases fluid and ventilatory requirements in pediatric vasodilatory septic shock. Indian J Crit Care Med. 2016;20(10):561-9.

38. Byrne L, Obonyo NG, Diab SD, Dunster KR, Passmore MR, Boon AC, Hoe LS, Pedersen S, Fauzi MH, Pimenta LP, et al. Unintended consequences: fluid resuscitation worsens shock in an ovine model of endotoxemia. Am J Resp Crit Care Med. 2018;198(8):1043-54.

39. Vincent JL, Sakr Y, Sprung CL, Ranieri VM, Reinhart K, Gerlach H, Moreno R, Carlet J, Le Gall JR, Payen D; Sepsis Occurrence in Acutely III Patients Investigators. Sepsis in European intensive care units: results of the SOAP study. Crit Care Med 2006; 34(2):344-353.

40. Boyd JH, Forbes J, Nakada TA, Walley KR, Russell JA. Fluid resuscitation in septic shock: a positive fluid balance and elevated central venous pressure are associated with increased mortality. Crit Care Med. 2011;39(2):259-65.

41. Sakr Y, Rubatto Birri PN, Kotfis K, Nanchal R, Shah B, Kluge S, Schroeder ME, Marshall JC, Vincent JL; Intensive Care Over Nations Investigators. Higher fluid balance increases the risk of death from sepsis: results from a large international audit. Crit Care Med 2017:45(3):386-394.

42. Marik PE, Linde-Zwirble WT, Bittner EA, Sahatjian J, Hansell D. Fluid administration in severe sepsis and septic shock, patterns and outcomes: an analysis of a large national database. Intensive Care Med. 2017;43(5):625-32.

43. Hippensteel JA, Uchimido R, Tyler PD, Burke RC, Han X, Zhang F, McMurtry SA, Colbert JF, Lindsell CJ, Angus DC, et al. Intravenous fluid resuscitation is associated with septic endothelial glycocalyx degradation. Crit Care. 2019; 23(1):259.

44. Marik PE. latrogenic salt water drowning and the hazards of a high central venous pressure. Ann Intensive Care. 2014;4:21

45. Monnet X, Julien F, Ait-Hamou N, Lequoy M, Gosset C, Jozwiak M, Persichini $\mathrm{R}$, Anguel N, Richard C, Teboul JL. Lactate and venoarterial carbon dioxide difference/arterial-venous oxygen difference ratio, but not central venous oxygen saturation, predict increase in oxygen consumption in fluid responders. Crit Care Med. 2013;41(6):1412-20.

46. Sennoun N, Montemont C, Gibot S, Lacolley P, Levy B. Comparative effects of early versus delayed use of norepinephrine in resuscitated endotoxic shock. Crit Care Med. 2007;35(7):1736-40.

47. Beck V, Chateau D, Bryson GL, Pisipati A, Zanotti S, Parrillo JE, Kumar A, Cooperative Antimicrobial Therapy of Septic Shock (CATSS) Database Research Group. Timing of vasopressor initiation and mortality in septic shock: a cohort study. Crit Care. 2014;18(3):R97.

48. Stolk RF, van der Poll T, Angus DC, van der Hoeven JG, Pickkers P, Kox M. Potentially inadvertent immunomodulation: norepinephrine use in sepsis. Am J Respir Crit Care Med. 2016;194(5):550-8.

\section{Publisher's Note}

Springer Nature remains neutral with regard to jurisdictional claims in published maps and institutional affiliations.

Ready to submit your research? Choose BMC and benefit from:

- fast, convenient online submission

- thorough peer review by experienced researchers in your field

- rapid publication on acceptance

- support for research data, including large and complex data types

- gold Open Access which fosters wider collaboration and increased citations

- maximum visibility for your research: over $100 \mathrm{M}$ website views per year

At BMC, research is always in progress.

Learn more biomedcentral.com/submissions 